\title{
PENGARUH BUDAYA ORGANISASI, KOMITMEN ORGANISASI DAN GAYA KEPEMIMPINAN TERHADAP KINERJA KARYAWAN
}

10.34005/akademika.v8i02.366

\author{
Asih Andayani \\ asih.andayani7@gmail.com \\ Universitas Mercubuana, Indonesia
}

\author{
Tjiptogoro Dinarjo Soehari \\ tjiptogd@yahoo.com \\ Universitas Mercubuana, Indonesia
}

\begin{abstract}
Commitment and leadership style both simultaneously and partially on the performance of employees of the National Professional Certification Board in Jakarta. The methodology used in this study is the Quantitative Method, a data processing method that explains the influence and the relationship stated by sentence. Quantitative analysis is used to see the causal factors. The variables used are Employee Performance $(Y)$ as the dependent variable while Organizational Culture (X1), Organizational Commitment (X2) and Leadership Style (X3) as independent variables. The variables used are Employee Performance $(Y)$ as the dependent variable while Organizational Culture (X1), Organizational Commitment (X2) and Leadership Style (X3) as independent variables. This research was conducted at the National Professional Certification Board with a population of 34 people and used a saturated sample.
\end{abstract}

Keywords: Organizational Culture, Organizational Commitment, Leadership Style and Employee Performance

\begin{abstract}
Abstrak: Penelitian ini bertujuan untuk mengetahui pengaruh budaya organisasi, komitmen organisasi dan gaya kepemimpinan baik secara simultan maupun parsial terhadap kinerja karyawan Badan Nasional Sertifikasi Profesi di Jakarta.Metodologi yang digunakan dalam penelitian ini adalah Metode Kuantitatif yaitu metode pengolahan data yang menjelaskan pengaruh dan hubungan yang dinyatakan dengan kalimat. Analisis kuantitatif digunakan untuk melihat faktor penyebab. Adapun variabel yang digunakan yaitu Kinerja Karyawan $(Y)$ sebagai variabel dependent sedangkanBudaya Organisasi (X1), Komitmen Organisasi (X2) dan Gaya Kepemimpinan (X3) sebagai variabel independent. Penelitian ini dilakukan di Badan Nasional Sertifikasi Profesi dengan populasi sebanyak 34 orang dan menggunakan sampel jenuh. Sehingga seluruh karyawan digunakan sebagai sampel. Persamaan regresi linear berganda $Y=1,623+$ $0,243 X 1+0,215 X 2+0,214 X 3$. Rsquare $=0,759, F=59,844$ (2) Budaya Organisasi menjadi faktor paling dominan terhadap Kinerja Karyawan; (3) Komitmen Organisasi dan Gaya Kepemimpinan memiliki pengaruh yang signifikan terhadap Kinerja Karyawan. Hasil dari Kinerja Karyawan adalah sebesar 1,419. Apabila X1, X2 dan X3 dianggap nol maka akan mempengaruhi kinerja karyawan sebesar 1,419 dalam skala likert 1-5 termasuk kategori sangat tidak baik.
\end{abstract}

Kata Kunci: Budaya Organisasi, Komitmen Organisasi, Gaya Kepemimpinan dan Kinerja Karyawan 


\section{PENDAHULUAN}

Badan Nasional Sertifikasi Profesi (BNSP) merupakan badan independen yang bertanggung jawab kepada Presiden yang memiliki kewenangan sebagai otoritas sertifikasi personil dan bertugas melaksanakan sertifikasi kompetensi profesi bagi tenaga kerja. Badan Nasional Sertifikasi Profesi dibentuk sesuai amanah Undang-Undang Nomor 13 Tahun 2013 tentang Ketenagakerjaan yang pembentukannya berdasarkan Peraturan Pemerintah Nomor 23 tahun 2004 tentang Badan Nasional Sertifikasi Profesi.

Tantangan yang dihadapi BNSP terfokus pada pelayanan kebutuhan pelanggan, tidak hanya pada kepuasan pelanggan (customer satisfaction) tetapi lebih berorientasi pada nilai (customer value). Jika ingin unggul maka BNSP harus mampu cepat tanggap terhadap kebutuhan pelanggan dengan konsekuensi organisasi memerlukan sumber daya manusia yang mempunyai keahlian dan kompeten di bidangnya. Untuk mewujudkan hal tersebut BNSP harus berorientasi pada pembentukan kualitas sumber daya manusia yang mampu menjawab tuntutan perubahan.

Selama 3 (tiga) tahun terakhir BNSP memiliki pertumbuhan yang amat cepat, terlihat dari sangat progresifnya jumlah permintaan lisensi, pelayanan informasi yang meningkat, meningkatnya jumlah tenaga kerja yang disertifikasi serta banyaknya jumlah masyarakat yang semakin paham akan sertifikasi kompetensi sebagaimana tertuang dalam laporan kinerja BNSP.Target Renstra sampai dengan tahun 2017 adalah 106\%, dengan total jumlah lembaga terealisasi sejumlah 859 lembaga. Jumlah tenaga kerja yang disertifikasi berdasarkan capaian kinerja sampai dengan tahun 2017 adalah 938.059 orang, atau tercapai 81,25\%. Jumlah tenaga asesor yang ditingkatkan kompetensinya sampai dengan tahun 2017 adalah 32.291 atau tercapai $430.54 \%$. Secara kuantitatif memang terlihat adanya peningkatan kinerja, tetapi jika dilihat dari kualitas pelayanan, jumlah SDM yang terbatas mengakibatkan kurang puasnya masyarakat dan terjadinya pengaduan ke Ombudsman.Dalam rangka memperoleh faktor-faktor strategik manajemen sumber daya manusia untuk meningkatkan kinerja karyawan, telah dilakukan pra penelitian menggunakan kuesioner terhadap 10 responden diperoleh faktor-faktor strategik Budaya Organisasi, Komitmen Organisasi dan Gaya Kepemimpinan yang selanjutnya dijadikan sebagai variabel independent.

Organisasi adalah entitas sosial yang terkoordinasi secara sadar, terdiri dari dua orang atau lebih dengan batasan yang relatif teridentifikasi, yang berfungsi secara berkelanjutan untuk mencapai seperangkat sasaran bersama (Torang, 2013:106). Robbins dikutip oleh Torang (2013:106). menyatakan bahwa organisasi adalah sistem peran, aliran aktivitas dan proses (pola hubungan kerja) dan melibatkan beberapa orang sebagai pelaksana tugas, yang dirancang untuk menjalankan tujuan bersama. 
Budaya organisasi (corporate culture) sering diartikan sebagai nilainilai, simbol-simbol yang dimengerti dan dipatuhi bersama, yang dimiliki suatu organisasi sehingga anggota organisasi merasa satu keluarga dan menciptakan suatu kondisi yang berbeda dengan organisasi lain.

Budaya organisasi merupakan faktor yang paling kritis dalam organisasi. Efektivitas organisasi dapat ditingkatkan dengan menciptakan budaya yang kuat, yang dapat digunakan untuk mencapai tujuan organisasi. Organisasi yang berbudaya kuat akan memiliki ciri khas tertentu sehingga dapat memberikan daya tarik bagi individu untuk bergabung.

Suatu budaya yang kuat merupakan perangkat yang sangat bermanfaat untuk mengarahkan perilaku, karena membantu karyawan untuk melakukan pekerjaan dengan lebih baik, sehingga setiap karyawan perlu memahami budaya dan bagaimana budaya tersebut terimplementasikan. Budaya organisasi merupakan suatu sistem dari makna organisasi/ arti bersama yang dianut dari para anggotanya yang membedakan organisasi dari organisasi lainnya, Budaya organisasi adalah kebiasaan yang terus berulang-ulang dan menjadi nilai (value) dan gaya hidup sekelompok individu dalam organisasi. Budaya organisasi adalah norma-norma yang telah disepakati untuk menuntun perilaku individu dalam organisasi. Budaya organisasi merupakan dasar bagi pimpinan dan staff/ anggota organisasi dalam membuat perencanaan atau strategi dan taktik dalam menyusun visi-misi untuk mencapai tujuan organisasi (Robbins, 2005 dalam Torang 2013:106). Budaya organisasi menunjukkan nilai, keyakinan, prinsip, tradisi, dan cara sekelompok orang beraktivitas dalam organisasi. Budaya organisasi merupakan hasil atau output organisasi (Thompson dan Stickland, 2001 dalam Torang 2013:106).

Berbagai definisi tentang budaya organisasi antara lain dinyatakan oleh sejumlah pakar. Kreitner dan Kinicki dalam Torang (2013:106) menyatakan bahwa budaya organisasi adalah nilai dan keyakinan bersama yang mendasari identitas. Menurut Narayana (2017:73) budaya organisasi adalah tradisi atau keyakinan organisasi yang membedakannya dari organisasi lain dan memberikan kehidupan tertentu pada kerangka dan struktur organisasi tersebut. Budaya dikonseptualisasikan sebagai keyakinan dan nilai bersama dalam organisasi yang membantu membentuk pola perilaku karyawan. Budaya organisasi adalah perekat normatif yang merekat organisasi. Budaya organisasi adalah penggerak yang mengakui usah dan kontribusi anggota organisasi dan memberikan pemahaman holistik tentang apa yang harus dicapai dan bagaimana cara mencapainya, bagaimana tujuan-tujuan saling terkait dan bagaimana karyawan bisa mencapai tujuan tersebut.

Cummings dan Worley (2009:521) mendefinisikan budaya secara singkat sebagai pola artefak, norma, nilai, dan asumsi dasar tentang bagaimana memecahkan masalah dalam organisasi. Budaya adalah proses pembelajaran sosial, hasil dari pilihan sebelumnya tentang dan 
pengalaman dengan strategi dan desain organisasi. Budaya juga merupakan dasar perubahan yang dapat memfasilitasi atau menghambat transformasi organisasi.

Dari berbagai pendapat pakar tentang budaya organisasi, bisa disimpulkan bahwa budaya organisasi adalah sekumpulan kebiasaan, nilai dan keyakinan bersama sebagai pedoman makna dan aturan perilaku bagi anggota organisasi yang menjadikan identitas organisasi dan membedakannya dari organisasi lain, budaya organisasi ini digunakan dalam rangka menjalankan tujuan bersama atau tujuan organisasi secara umum.

Budaya organisasi terdiri dari nilai dan keyakinan bersama yang memberikan makna dan aturan perilaku bagi anggota organisasi. Budaya organisasi terlihat dalam norma perilaku yang diharapkan, nilai, filosofi, ritual dan simbol yang digunakan oleh karyawan dan mengalmai perkembangan dengan berjalannya waktu, budaya organisasi akan menjadi stabil dalam waktu bertahun tahun (Mathis dan Jackson, 2010:78).

Komitmen organisasi telah menjadi bahasan penting bagi kajian tentang manajemen dan perilaku organisasi. Locke (2009:28) mendefinisikan komitmen organisasi mengacu pada keterlibatan seseorang dengan organisasi, perasaan kewajiban terhadap organisasi, dan biaya yang dirasakan seseorang terkait dengan keluar dari organisasi tersebut. Robbins dan Judge (2013:75) menyatakan bahwa komitmen organisasi menunjukkan tingkat seorang karyawan mengidentifikasi organisasi tertentu serta tujuan dan keinginannya untuk tetap menjadi anggota organisasi tersebut. Keterikatan emosional pada organisasi dan keyakinan akan nilai-nilainya dianggap sebagai standar puncak dari komitmen karyawan. Dua pakar bidang perilaku organisasi yaitu Hellriegel dan Slocum (2011:91) menyatakan bahwa komitmen organisasi adalah tingkat keterlibatan karyawan dalam organisasi dan identifikasi dengan organisasi tersebut. Komitmen organisasi memengaruhi seseorang untuk tetap bekerja pada satu perusahaan. Karyawan yang bekerja pada jangka waktu yang lama cenderung lebih berkomitmen kepada organisasi 132ndicator132 karyawan yang bekerja dalam jangka waktu pendek. Mathis dan Jackson (2010:158) mendefinisikan komitmen organisasi sebagai tingkat kepercayaan dan penerimaan karyawan terhadap tujuan organisasi serta keinginannya untuk tetap bersama organisasi tersebut. Dari sejumlah pendapat pakar di atas dapat disimpulkan bahwa komitmen organisasi adalah tingkat identifikasi, keterlibatan dan ikatan emosional seseorang dengan organisasi, dan keinginan untuk tetap menjadi anggota organisasi. Tingkat komitmen dipengaruhi oleh lama kerja karyawan dalam satu organisasi.

Terry mendefinisikan kepemimpinan sebagai "leadership is the activity of influencing people to strive willingly for mutual objectives" (aktifitas mempengaruhi orang banyak untuk berusaha dengan sukarela demi mencapai tujuan bersama)"a leader is not a pusher; he pulls rather 
than pusher" (pemimpin bukanlah pendorong tapi penggerak yang menarik orang lain) (Torang, 2013:62). Badeni (2014:128) menyatakan bahwa kepemimpinan tidak sama dengan manajemen organisasi. Kepemimpinan adalah bagian dari manajemen dengan wilayah jangkauan yang lebih luas. Pemimpin berperan utama dalam memengaruhi orang lain agar secara sukarela berusaha mencapai tujuan yang telah ditetapkan pemimpin. Kepemimpinan adalah suatu proses memengaruhi orang lain agar berperilaku sesuai dengan yang diinginkan pemimpin tanpa ada rasa terpaksa dari si pengikut untuk mencapai tujuan tertentu. Tujuan ini tidak terbatas pada pencapaian tujuan organisasi saja tetapi termasuk di dalamnya tujuan individu yang bersangkutan. Manajer mencapai hasil dengan mengarahkan aktivitas-aktivitas orang lain, sedangkan pemimpin menciptakan suatu visi dan menginspirasikan orang lain untuk mencapai visi tersebut, serta agar orang lain tersebut mengembangkan diri mereka melebihi kemampuan-kemampuan normal. Pemimpin yang handal mungkin menjadi manajer yang lemah jika mereka buruk dalam melakukan perencanaan untuk mengarahkan pengikutnya (Badeni, 2014:128).

Fahmi (2012:58) merangkum sejumlah pendapat pakar tentang kepemimpinan sebagai berikut: Stephen P. Robbins mengatakan, bahwa kepemimpinan adalah kemampuan untuk mempengaruhi suatu kelompok ke arah tercapainya tujuan; Richard L. Daft mengatakan bahwa kepemimpinan adalah kemampuan mempengaruhi orang yang mengarah kepada pencapaian tujuan; G. R. Terry mendefinisikan kepemimpinan sebagai "the activity of influencing people to strive willingly for mutual objectives"; dan. Ricky W. Griffin mengatakan bahwa pemimpin adalah individu yang mampu mempengaruhi perilaku orang lain tanpa harus mengandalkan kekerasan; pemimpin adalah individu yang diterima oleh orang lain sebagai pemimpin.

Pamudji (1985) dikutip oleh Badeni (2014:143) mengatakan bahwa kepemimpinan memiliki tiga variabel utama yang harus dipertimbangkan, yaitu: 1) Pemimpin, adalah seorang yang menjalankan fungsi kepemimpinan, 2) Pengikut, adalah sekelompok orang yang berkedudukan untuk mengikuti, 3) Situasi dan kondisi, adalah situasi yang melingkupi kepemimpinan.

Berbagai pendapat pakar tersebut memberikan kesimpulan bahwa kepemimpinan berperan penting dan memiliki jangkauan melampaui manajemen. Kepemimpinan mempengaruhi bawahan melalui pengetahuan, sikap dan perilaku, agar bawahan bertindak secara sukarela demi mencapai tujuan organisasi dan tujuan individu tersebut.

Fahmi (2012:226) mendefinisikan kinerja sebagai "hasil yang diperoleh oleh suatu organisasi yang bersifat profit oriented dan non profit oriented selama satu periode waktu. Fahmi juga mengutip Armstrong dan Baron (1998:15) yang mendefinisikan Kinerja merupakan hasil pekerjaan yang mempunyai hubungan kuat dengan tujuan strategis organisasi, kepuasan konsumen dan memberikan kontribusi ekonomi (Fahmi, 
2012:226). Kinerja terkait dengan unjuk kerja atau hasil kerja yang dihasilkan atau perilaku nyata oleh karyawan yang ditampilkan sesuai dengan peran seorang karyawan dalam organisasi (Hariandja, 2009:195). Kinerja adalah suatu perbuatan, suatu prestasi, suatu parneran keterampilan Matis dan Jacson menyatakan bahwa perbaikan kinerja individu maupun kelompok adalah pusat perhatian untuk meningkatkan kinerja organisasi (Noor, 2013:270). Kinerja adalah fungsi kapastitas untuk melakukan sesuatu pekerjaan, kesempatan untuk melakukan suatu pekerjaan dan kemauan untuk melakukan suatu pekerjaan. Kinerja seseorang merupakan gabungan dari kemampuan, usaha, dan kesempatan yang dapat diukur dari akibat yang dihasilkan. Kinerja adalah tentang apa yang dikerjakan dan bagaimana cara mengerjakannya. Kinerja merupakan hasil pekerjaan yang mempunyai hubungan kuat dengan tujuan strategis organisasi, kepuasan konsumen, dan memberikan kontribusi ekonomi (Noor, 2013:271).

Dari berbagai pendapat tentang kinerja tersebut bisa disimpulkan bahwa kinerja adalah kapasitas, kesempatan dan kemauan untuk memberikan hasil kerja atau unjuk kerja yang didasarkan dari gabungan kemampuan, usaha, dan kesempatan karyawan baik secara individual ataupun kelompok yang sejalan dengan tujuan strategis organisasi yang menjadi pusat perhatian bagi organisasi untuk ditingkatkan karena perbaikan kinerja karyawan akan berdampak langsung pada kinerja organisasi.

\section{METODE}

Jenis penelitian ini adalah statistik deskriptif, dengan pendekatan kuantitatif.Penelitian ini dilakukan di Badan Nasionala Sertifikasi Profesi. Penelitian ini menggunakan metode analisis dengan SPSS versi 24.

Teknik pengambilan sampel dalam penelitian ini menggunakan sampling jenuh dimana semua anggota populasi digunakan sebagai sampel yaitu seluruh karyawan Badan Nasional Sertifikasi Profesi dengan jumlah 34 orang.

\section{HASIL DAN PEMBAHASAN}

Dari populasi dan sampel di dapatkan hasil karakteristik responden berdasarkan jenis kelamin perempuan, yakni perempuanlebih banyak sebanyak 19 orang $(55,9 \%)$. Berdasarkan usia lebih banyak berusia antara 30-40 tahun sebanyak 17 orang $(50,0 \%)$. Berdasarkan lama bekerja/ Penempatan lebih banyak 5-10 tahun dan $>10$ tahun yang masing-masing sebanyak 10 orang $(29,4 \%)$. Berdasarkan pendidikan terakhir lebih banyak berpendidikan S1 sebanyak 16 orang $(47,1 \%)$.

Uji validitas dilakukan, jika $r$ hitung $>r$ tabel $=0,30$ maka dikatakan valid dengan $\alpha=0,05$. Uji Validitas variabel Budaya Organisasi $\left(X_{1}\right)$ terdiri 
dari 18 pernyataan dinyatakan valid, variabel Komitmen Organisasi (X2) terdiri dari 16 pernyataan dinyatakan valid, variabel Gaya Kepemimpinan (X3) terdiri dari 22 pernyataan dinyatakan valid dan variabel Kinerja Karyawan $(Y)$ terdiri dari 17 pernyataan, terdapat pernyataan yang tidak valid sebanyak 7 pernyataan sehingga tidak dapat digunakan. Sehingga total penyataan yang digunakan peneliti untuk uji selanjutnya sebanyak 56 pernyataan.

Uji reliabilitas dalam penelitian ini yaitu metode Cronbach's Alpha. Jika $r$ hitung $>r$ tabel $=0,60$ maka kuesioner tersebut reliabel, sedangkan jika sebaliknya maka tidak reliabel.Berdasarkan hasil reliabel Gaya Kepemimpinan (X1), Komitmen Organisasi (X2), Gaya Kepemimpinan (X3) dan Kinerja Karyawan (Y). Yaitu 0,870; 0,687; 0,950; 0,845> 0,60 sehinga dapat dinyatakan reliabel.

Pengujian normalitas dilakukan jika Uji Kolmogorov-Smirnov Sig $\geq$ 0,05 maka data berdistribusinormal. Jika Uji Kolmogorov-Smirnov Sig < 0,05 maka data berdistribusi tidaknormal.Dari hasil uji normalitas Budaya Organisasi $(\mathrm{X} 1)=0,0200>0,05$ dinyatakan normal,Komitmen Organisasi $(\mathrm{X} 2)=0,114>0,05$ dinyatakan normal, Gaya Kepemimpinan $(\mathrm{X} 3)=$ $0,171<0,05$ dinyatakan normal dan Kinerja Karyawan $(Y)=0,200>0,05$ dinyatakan normal. Hasil uji normalitas menunjukan nilai signifikan masing-masing variable sehingga data keempat veriabel terdistribusi normal.

Uji asumsi multikolinieritas pengujian Variance Inflation Factor (VIF), jika nilai VIF atas variabel $\mathrm{X}<10$ maka tidak terjadi multikolinieritas. Dari data hasil uji, bahwa VIF $<10$ yaitu Budaya Organisasi $(X 1)=1.207<$ 10 , Komitmen Organisasi $(\mathrm{X} 2)=1.328<10$ dan Gaya Kepemimpinan $(\mathrm{Y})=$ $1,276<10$, maka dikatakan data tidak terjadi multikolinearitas.

Uji Heteroskedastisitas, terlihat dari dari data hasil uji Scatter Plotbahwa tidak ada pola yang jelas seperti titik-titik melebar di atas dan dibawah angka 0 pada sumbu $Y$, jadi titik-titik menyebar acak, dan tidak membentuk pola tertentu. Hal ini, bisa disimpulkan bahwa data yang diuji tidak terjadi heteroskedastisitas.

Analisa Regresi Linier Berganda

Tabel 1. Hasil Analisis Regresi Linier Berganda

\begin{tabular}{lccccc}
\hline \multicolumn{7}{c}{ Model } & \multicolumn{7}{c}{ Unstandardized $^{\text {Coefficients }}$} & \multicolumn{2}{c}{$\begin{array}{c}\text { Standardized } \\
\text { Coefficients }\end{array}$} & \multirow{2}{*}{ t } & Sig. \\
\cline { 2 - 5 } & $\mathbf{B}$ & $\begin{array}{c}\text { Std. } \\
\text { Error }\end{array}$ & Beta & & \\
\hline (Constant) & 1,623 & 0,345 & & 4,710 & 0,000 \\
\hline Lingkungan Kerja & 0,243 & 0,074 & 0,399 & 3,306 & 0,002 \\
\hline Kompetensi & 0,215 & 0,095 & 0,286 & 2,259 & 0,031 \\
\hline Kompensasi & 0,214 & 0,074 & 0,361 & 2,907 & 0,007 \\
\hline
\end{tabular}

a. Dependent Variable: Kinerja Karyawan

Sumber : Hasil Pengolahan Data menggunakan SPSS 24 
Diperoleh persamaan regresi sebagai berikut:

$Y=1,623+0,243 X_{1}+0,215 X_{2}+0,214 X_{3}$

1. Dari persmaan diatas didapat bahwa kinerja karyawan BNSP jika tidak ada atau dipengaruhi Variabel X1, X2 dan X3 atau sma sengan nol maka kinerjanya adalah sebesar 1.625 .

2. Jika terjadi peningkatan/kenaikan pada variabel budaya organisasi (X1) dalam 1 satuan maka diperkiraan akan terjadi peningkatan kinerja karyawan sebesar 0,243 atau sebesar $24,3 \%$. Variabel budaya organisasi (X1) dalam penelitian ini memiliki pengaruh positif terhadap kinerja karyawan berarti jika budaya organisasi ditingkatkan maka kinerja karyawan BNSP akan meningkat.

3. Jika terjadi peningkatan/kenaikan pada variabel komitmen organisasi (X2) dalam 1 satuan maka diperkiraan akan terjadi peningkatan kinerja karyawan sebesar 0,215 atau sebesar $21,5 \%$. Variabel komitmen organisasi (X2) dalam penelitian ini memiliki pengaruh positif terhadap kinerja karyawan berarti jika komitmen organisasi di tingkatkan maka maka kinerja karyawan BNSP akan meningkat.

4. Jika terjadi peningkatan/kenaikan pada variabel gaya kepemimpinan (X3) dalam 1 satuan maka diperkiraan akan terjadi peningkatan kinerja karyawan sebesar 0,214 atau sebesar $21,4 \%$. Variabel gaya kepemimpinan (X3) dalam penelitian ini memiliki pengaruh positif terhadap kinerja karyawan berarti jika gaya kepemimpinan di tingkatkan maka maka kinerja karyawan BNSP akan meningkat.

Dari hasil perhitungan, nilai $F$ terlihat $F$ hitung $>F$ tabel bahwa 17,623>2,922, maka Ho ditolak yang berarti signifikan. Berdasarkan probabilitas hasil analisa diperoleh nilai 0,000 $<0,05$ berarti Ho ditolak dan $\mathrm{Ha}$ diterima. Dapat disimpulkan bahwa Budaya Organisasi (X1), Komitmen Organisasi (X2) dan Gaya Kepemimpinan (X3) secara bersama-sama berpengaruh signifikan terhadap Kinerja Karyawan (Y).

Nilai $R$ Square sebesar 0,759 . Hal ini menunjukkan bahwa variabel lingkungan kerja (X1), kompetensi (X2), dan kompensasi (X3) menjelaskan terhadap variabel kinerja karyawan $(Y)$ sebesar 75,9 \%. Sedangkan sisanya (100 \% - 75,9 \%) yaitu $24,1 \%$ kinerja karyawan(Y) dijelaskan oleh faktor-faktor lain diluar penelitian ini.

Hasil pengujian hipotesis menunjukkan variabel budaya organisasi menghasilkan thitung sebesar 3,306 lebih besar dari tabel sebesar 2,037 dan nilai signifikansi (Sig) sebesar 0,002 lebih kecil dari nilai level of significant $5 \%(\alpha=0.05)$, maka hipotesis Ho ditolak dan Ha diterima artinya variabel budaya organisasi secara parsial berpengaruh positif dan signifikan terhadap kinerja karyawan BNSP. 
Variabel komitmen organisasi menghasilkan menghasilkan thitung sebesar 2,259 lebih besar dari tabel sebesar 2,037 dan nilai signifikansi (Sig) sebesar 0,031 lebih kecil dari nilai level of significant $5 \%(\alpha=0.05)$, maka hipotesis Ho ditolak dan Ha diterima artinya variabel komitmen organisasi secara parsial berpengaruh positif dan signifikan terhadap kinerja karyawan BNSP.

Variabel gaya kepemimpinan menghasilkan thitung sebesar 2,907 lebih besar dari ttabel sebesar 2,037 dan nilai signifikansi (Sig) sebesar 0.007 lebih kecil dari nilai level of significant $5 \%(\alpha=0.05)$, maka hipotesis Ho ditolak dan Ha diterima artinya variabel gaya kepemimpinan secara parsial berpengaruh positif signifikan terhadap kinerja karyawan BNSP.

Diantara ketiga variabel bebas ternyata variabel budaya organisasi paling berpengaruh terhadap kinerja karyawan (24,3\%), selanjutnya variabel komitmen organisasi $(21,5 \%)$ dan paling rendah variabel gaya kepemimpinan $(21,4 \%)$. Dengan demikian untuk meningkatkan kinerja karyawan BNSP lebih efektif dengan meningkatkan budaya organisasi.

\section{PEMBAHASAN}

Pengaruh Budaya Organisasi terhadap Kinerja Karyawan

Hasil penelitian menunjukkan bahwa budaya organisasi secara parsial berpengaruh positif dan signifikan terhadap kinerja karyawan BNSP. Hal ini ditunjukkan dengan thitung $(3,306)$ lebih besar dari tabel $(2,037)$ dan nilai signifikansi $(0,002)$ lebih kecil dari nilai level of significant $5 \%(\alpha=0.05)$.

Hasil penelitian ini sesuai dengan penelitian Porwani dan Zunaidah (2009), Waliningsuci, Musadieq, dan Hamid (2011), Sokro (2012), Aftab, Rana, dan Sarwar (2012), Al-Shurafat, Mohammad Said dan Abdul Halim, Bahyah (2018), Khaliq dan Marnis (2014), His-Ying Hsieh (2015), Ilham, R. (2018), yang menunjukkan budaya organisasi secara parsial memiliki pengaruh positif dan signifikan terhadap kinerja.

Pada dasarnya setiap orang yang berada dalam sebuah organisasi berusaha untuk membentuk dan menentukan sesuatu yang dapat mengakomodasi kepentingan semua pihak agar dapat menjalankan aktivitasnya. Sejauh mungkin sesuatu yang diharapkan tersebut tidak berbenturan dengan sikap dan perilaku dari masing-masing individu. Sesuatu yang dimaksud adalah budaya yang terbentuk dari nilai, keyakinan, anggapan, harapan dan sebagainya.

Budaya organisasi merupakan nilai keyakinan bersama yang mendasari identitas perusahaan. budaya organisasi merupakan asset tak berwujud milik dari sebuah perusahaan. Budaya organisasi dianggap sebagai asset yang dapat meningkatkan kinerja organisasi. Dalam hal ini budaya organisasi selalu mempunyai dampak positif terhadap perkembangan sebuah organisasi.

Pengaruh Komitmen Organisasi terhadap Kinerja Karyawan 
Hasil penelitian menunjukkan bahwa komitmen organisasi secara parsial berpengaruh positif dan signifikan terhadap kinerja karyawan BNSP. Hal ini ditunjukkan dengan thitung $(2,259)$ lebih besar dari ttabel $(2,037)$ dan nilai signifikansi $(0,031)$ lebih kecil dari nilai level of significant $5 \%(\alpha=0.05)$.

Hasil penelitian ini sesuai dengan penelitian Mguqulwa, Nomakhuze (2008), Al-Shurafat, Mohammad Said dan Abdul Halim, Bahyah (2018), Ilham, R. (2018) yang menunjukkan komitmen organisasi secara parsial memiliki pengaruh positif dan signifikan terhadap kinerja.

Menurut Robbins dan Judge (2014), berpendapat bahwa komitmen organisasi adalah sampai tingkat mana seseorang karyawan memihak pada suatu organisasi tertentu dan tujuan-tujuannya dan berniat memelihara keanggotaan dalam organisasi itu. Komitmen organisasi yang tinggi berarti terdapat kepemihakan kepada organisasi yang tinggi pula. Komitmen sebagai prediktor kinerja seseorang merupakan prediktor yang lebih baik dan bersifat global, dan bertahan dalam organisasi sebagai suatu keseluruhan daripada kepuasan kerja semata.

Bagi karyawan yang memilki komitmen organisasi yang tinggi, pencapaian tujuan organisasi merupakan hal yang penting. Komitmen organisasi yang kuat dalam diri individu akan menyebabkan individu tersebut berusaha keras mencapai tujuan organisasi dan kemauan mengerahkan usaha atas nama organisasi guna meningkatkan kinerja. Dengan kata lain, individu dengan komitmen organisasi tinggi akan menunjukkan kinerja yang baik dalam upaya tercapainya tujuan dari organisasi tersebut.

Pengaruh Gaya Kepemimpinan terhadap Kinerja Karyawan

Hasil penelitian menunjukkan bahwa gaya kepemimpinan secara parsial berpengaruh positif signifikan terhadap kinerja karyawan BNSP. $\mathrm{Hal}$ ini ditunjukkan dengan thitung $(2,907)$ lebih besar dari tabel $(2,037)$ dan nilai signifikansi (0.007) lebih kecil dari nilai level of significant $5 \%(\alpha=$ 0.05).

Hasil penelitian ini sesuai dengan penelitian Nurjanah (2008), Sri Porwani dan Zunaidah (2009), Hasanuddin (2011), Waliningsuci, Musadieq, dan Hamid (2011), Morales, Jiménez-Barrionuevo, and Gutiérrez-Gutiérrez (2011), Agie Irawan Supardi (2014), Tampi (2014), Hassan and Hatmaker (2015), Khaliq dan Marnis (2014), Babatunde, Osabiya (2015), His-Ying Hsieh (2015). Robertus dan Yuniawan (2016) yang menunjukkan gaya kepemimpinan secara parsial memiliki pengaruh positif dan signifikan terhadap kinerja.

Dalam organisasi kemampuan untuk mempengaruhi, menggerakkan dan mendorong bawahan untuk melakukan sesuatu didasarkan pada kekuasaan yang dimiliki pemimpinnya. Keefektifan seorang pemimpin dalam mempengaruhi pengikutnya, sangat ditentukan oleh seberapa besar seseorang mempunyai kekuasaan. Semakin besar 
kekuasaan, maka akan semakin mudah bagi seorang pemimpin dalam mempengaruhi pengikutnya.

Dalam upaya mempengaruhi tersebut seorang pemimpin menerapkan gaya yang berbeda-beda dalam setiap situasi. Untuk menerapkan gaya kepemimpinan yang efektif harus diawali dengan mendiagnosis situasi dengan sebaik-baiknya. Situasi berkaitan dengan kapan, tuntutan iklim organisasi, harapan serta kemampuan atasan dan bawahan.

Gaya kepemimpinan merupakan berbagai pola tingkah laku yang disukai oleh pemimpin dalam proses mengarahkan dan mempengaruhi pekerja. Dari pengertian tersebut terungkap bahwa apa yang dilakukan seorang pimpinan mempunyai pengaruh terhadap bawahan. Pengaruh tersebut dapat bersifat positif seperti membangkitkan semangat, motivasi dan kegairahan kerja ataupun dapat bersifat sebaliknya tergantung penerimaan bawahannya terhadap gaya kepemimpinan tersebut.

Pengaruh Budaya Organisasi, Komitmen Organisasi dan Gaya Kepemimpinan terhadap Kinerja Karyawan

Hasil penelitian menunjukkan bahwa budaya organisasi, komitmen organisasi dan gaya kepemimpinan secara simultan berpengaruh signifikan terhadap kinerja karyawan BNSP. Hal ini ditunjukkan dengan nilai $F_{\text {hitung }}(17,623)$ lebih besar dari $F_{\text {tabel }}(2,922)$ dan nilai signifikansi $(0,000)$ lebih kecil dari nilai level of significant $5 \%(\alpha=0.05)$.

Hasil penelitian ini sesuai dengan penelitian Porwani dan Zunaidah (2009) yang menunjukkan budaya organisasi dan gaya kepemimpinan secara simultan memiliki pengaruh signifikan terhadap kinerja. Selain itu sesuai dengan penelitian Hakim dan Hadipapo (2015) yang menunjukkan budaya organisasi dan komitmen organisasi secara simultan memiliki pengaruh signifikan terhadap kinerja. Penelitian Mustikaningsih, Y. S. dan Handayani, R. (2014) menunjukkan komitmen organisasi dan gaya kepemimpinan secara simultan memiliki pengaruh signifikan terhadap kinerja.

Organisasi terdiri dari berbagai elemen terintegrasi dan dibentuk oleh budaya yang lebih besar. Budaya organisasi dibangun untuk mengatasi tantangan di masa yang lalu. Berbagai kebijakan, prosedur, filosofi organisasi, kebiasaan dan lain-lain merupakan respon terhadap situasi dan tantangan di masa yang lalu, yang dapat berpengaruh terhadap kinerja karyawan di organisasi tersebut.

Faktor yang lain yang dirasakan dapat mempengaruhi kinerja karyawan adalah komitmen organisasi dan gaya kepemimpinan. Komitmen karyawan pada organisasi adalah sikap karyawan dalam keterlibatan perannya dalam organisasi, kesetiaannya dalam organisasi dan rasa menjadi bagian organisasi.Komitmen organisasi yang kuat sangat dibutuhkan oleh organisasi untuk dapat menjalankan aktivitasnya sesuai dengan visi dan misi yang telah ditetapkan. 
Keberhasilan suatu organisasi jugabanyak dipengaruhi oleh pemimpinnya, maka pemimpin bertanggungjawab atas keberhasilan atau kegagalan suatu pekerjaan. Gaya kepemimpinan yang baik, dapat dilihat dari kemampuan membimbing, mengarahkan, membangun motivasi kerja, mengendalikan organisasi, membangun team work, menciptakan kondisi kerja yang sehat, memberikan pengawasan dan membawa para pengikutnya kepada sasaran yang dituju sesuai dengan misi yang telah ditentukan. Para pemimpin memiliki suatu ciri tersendiri dalam mengarahkan, membimbing karyawannya yang biasa dikenal dengan gaya kepemimpinan.

\section{KESIMPULAN}

Berdasarkan data yang diperoleh dan dianalisis, dapat disimpulkan hal-hal sebagai berikut: 1) Budaya organisasi secara parsial berpengaruh positif dan signifikan terhadap kinerja karyawan BNSP. Budaya Organisasi memiliki analisis regresi terbesar terhadap kinerja karyawan sehingga menjadi prioritas pertama lembaga untuk mengambil kebijakan dalam rangka meningkatkan kinerja karyawan, 2) Komitmen organisasi secara parsial berpengaruh positif dan signifikan terhadap kinerja karyawan BNSP. Komitmen Organisasi memiliki analisis regresi urutan kedua terhadap kinerja karyawan sehingga menjadi prioritas kedua lembaga untuk mengambil kebijakan dalam rangka meningkatkan kinerja karyawan. 3) Gaya kepemimpinan secara parsial berpengaruh positif signifikan terhadap kinerja karyawan BNSP. Gaya Kepemimpinan memiliki analisis regresi ketiga terhadap kinerja karyawan sehingga menjadi prioritas ketiga lembaga untuk mengambil kebijakan dalam rangka meningkatkan kinerja karyawan. 4) Budaya organisasi, komitmen organisasi dan gaya kepemimpinan secara simultan berpengaruh signifikan terhadap kinerja karyawan BNSP. Jika Budaya Organisasi, Komitmen Organisasi dan Gaya Kepemimpinan secara bersama - sama ditingkatkan maka akan meningkatkan kinerja karyawan.

\section{DAFTAR PUSTAKA}

Aamodt, M.G. (2010). Industrial/ Organizational Psychology: An Appied Approach. Sixth Edition. USA : Wadsworth Cencange Learning.

Aftab, H., Rana, T., and Sarwar, A. (2012). An Investigation of the Relationship between Organizational Culture and the Employee's Role Based Performance: Evidence from the Banking Sector. International Journal of Business and Commerce, 2, 1-13.

Agie Irawan Supardi. (2014). Pengaruh Budaya Organisasi dan Gaya Kepemimpinan Terhadap Kinerja Karyawan (Studi Kasus Pada Karyawan Bagian Produksi PT. Paparti Pertama Tahun 2014. S1 
Manajemen Bisnis Telekomunikasi dan Informatika. Bandung : Universitas Telkom.

Al-Shurafat, Mohammad Said and Abdul Halim, Bahyah. (2018). A Review of Organisational Culture and Organizational Commitment. IOSR Journal of Business and Management (IOSR-JBM) e-ISSN: 2278487X, p-ISSN: 2319-7668. Volume 20, Issue 3. Ver. 5 (March. 2018), PP. 21-26

Anwar, Syamsul. (2015). Pengaruh Budaya Organisasi Dan Gaya Kepemimpinan Terhadap Komitmen Organisasi Purna Paskibraka Indonesia Kabupaten Kutai Kartanegara. Jurnal Psikologi. Vol. 4, No. 1, 2015: 41-52, diakses pada 20 Februari 2016

Babatunde, Osabiya. (2015). The Impact of Leadership Style on Employee's Performace in an Organizational. Public Policy and Administration Research. 5(1). PP. 193-206.

Badeni. (2014). Kepemimpinan dan Perilaku Organisasi. Bandung: Alfabeta

Champoux, Joseph E. (2011). Organizational Behavior: Integrating Individuals, Groups, and Organizations. $4^{\text {th }}$ Edition. Taylor and Francis.

Cheng-Kang Yuan and Chuan-Yin Lee. (2011). Exploration of Construct Model Lingking Leadership Types Organizational Culture Employees Performance and Leadership Performance. Procedia - Social and Behavioral Sciences 25 (2011) $123-136$

Collings, David G., \& Wood, G. (2009). Human Resource Management: a CriticalApproach. New York: Rout Ledge.

Cummings, Thomas G., dan Worley, Christopher G. (2009). OrganizationDevelopment \& Change. 9th Edition. Canada: SouthWestern Cengage Learning.

Dessler, Gary. (2015). Manajemen Sumber Daya Manusia. Jakarta: Salemba Empat.

Fahmi, Irham. (2012). Manajemen Kepemimpinan: Teori dan Aplikasi. Bandung: Alfabeta.

Gita, Robertus dan Yuniawan, Ahyar. (2016). Pengaruh Gaya kepemimpinan Transformasional motivasi kerja, dan Budaya Organisasi Terhadap Kinerja Karyawan (Studi pada PT BPR Arta Utama Pekalongan). Jurnal Studi Manajemen \& Organisasi 13 (2016)Desember 161 - 170. 
Hakim, Abdul. dan Hadipapo, Anwar. (2015). Peran Kepemimpinan dan Budaya Organisasi Terhadap Kinerja Sumber Daya Manusia di Wawotobi. EKOBIS Vol 16. No.1, Januari 2015 hal 1-11.

Hasanuddin. (2011). Pengaruh Budaya Organisasi dan Kepemimpinan terhadap Motivasi Kerja serta dampaknya pada Kinerja Organisasi (Studi Kasus Bappeda Kab Aceh Besar). Tesis. Magister Manajemen. Program Pascasarjana. Banda Aceh: Universitas Syiah Kuala.

Hassan, Shahidul and Hatmaker, Deneen M. (2015). Leadership Performance of Public Employees: Effect of Quality and Characteristic of Manager -Employee Relationships. Journal of Public Administration Research and Theory. Volume 25, Issue 4, 1 October 2015. Pages 11127-1155.

Hellriegel, D dan Slocum, J. W. (2011). Organizational Behavior. Mason: South-Western, Cengage Learning

Herrmann, Daniel and Felfe, Jorg. (2012). Effects Leadership Style, Creativity Technique and Personal Initiative on Employee Creativity. British Journal of Management. Volume 25. Issue 2. 29 October 2012.

His-Ying Hsieh. (2015). The Influence of Leadership Style and Corporate Culture on Organizational Commitment and Job Performance - A Comparison between a Local 5-star Hotel and an International Chain Hotel in Taiwan. Proceedings of the Third Asia-Pacific Conference on Global Business, Economics, Finance and Banking (AP15Singapore Conference), ISBN: 978-1-63415-751-3 17-19 July 2015 Paper ID: S539

Ilham, R. (2018). The Impact of Organizational Culture and Leadership Style on Job Satisfaction and Employee Performance. Journal of Advanced Management Science Vol. 6, No. 1, March 2018

lqbal N, Anwar S, and Haidar N. (2015). Effect Of Leadership Style on Employee Performance. Arabian Journal of Business and $r A$ Management Review, 5 (5).

Khaliq, Ilham dan Marnis. (2014). Pengaruh Budaya Organisasi, Disiplin Kerja dan Kepemimpinan terhadap Kinerja Pegawai pada Sekretariat Daerah Kabupaten Indragiri Hulu. Jurnal Tepak Manajemen Bisnis, Vol VII, No.1

Landy, Frank J. and Conte, Jeffrey M. (2013). Work in the 21st Century; An Introduction of Industrial and Organizational Psychology. United States of America: JohnWiley \& Sons Inc. 
Locke, E.A. (2009). Esensi Kepemimpinan. Terjemahan Aris Ananda. Jakarta: Spektrum

Luthans, Fred. (2011). Perilaku Organisasi. Yogyakarta: Penerbit Andi.

Marihot, Tua Efendi Hariandja. (2009). Manajemen Sumber Daya Manusia: Pengadaan, Pengembangan, Pengkompensasian, Peningkatan Produktivitas Pegawai. Jakarta: Grafindo.

Mathis, R.L. dan Jackson, J.H. (2010). Manajemen Sumber Daya Manusia. Terjemahan Jimmy Sadeli dan Bayu Prawira Hie. Jakarta: Salemba Empat.

McShane, Steven L. and Glinow, M.A.V.(2011). Organizational Behavior. $3^{\text {rd }}$ Edition. New York: McGraw-Hill

Mguqulwa, Nomakhuze. (2008). The Relationship between Organisation Commitmen and Work Performance In an Agricultura Company. Thesis. Industrial And Organisational Psychology. South Africa: University Of South Africa.

Morales, Garcia, V.J., Jiménez-Barrionuevo., and Gutiérrez-Gutiérrez. (2011). Trasformational Leadership Influence on Organizational Performace through Organizational Learning and Innovation. Journal of Business Research, 65(7), 1040-1050. https://doi.org/10.1016/j.jbusres.2011.03.005

Mustikaningsih, Y. S. dan Handayani, R. (2014). Pengaruh Gaya Kepemimpinan, Budaya Organisasi, Komitmen Organisasi dan Remunerasi Terhadap Kinerja Karyawan. ISSN : 085-1442 Media Ekonomi dan Manajemen Vol. 29 No. 1 Januari 2014

Narayana, A. (2017). A Critical Review of Organizational Culture on Employee Performance, American Journal of Enggineering and Technology Management. Vol 2(5), 72-76.

Noor, Any. (2013). Manajemen Event. Bandung: Alfabeta.

Nurjanah. (2008). Pengaruh Gaya Kepemimpinan dan Budaya Organisasi terhadap Komitmen Organisasi dalam Meningkatkan Kinerja Karyawan (Studi pada Biro Lingkup Departemen Pertanian). Skripsi. Semarang: UNDIP.

Owoyemi O.O and Ekwoaba J.O. (2014). Organizational Cultur A Tool for Management to Control, Motivate and Enhance Employees Performance. American Journal of Business and Management Vol. 3, No. 3, 2014, 168-177 
Porwani, Sri dan Zunaidah. (2009). Pengaruh Budaya Organisasi dan Gaya Kepemimpinan Transformasional Terhadap Kinerja Karyawan PT Tambang Batubara Bukit Asam (persero) Tanjung Enim. Orasi Bisnis Edisi ke-2. hal. 68-81.

Priyanto, Duwi. (2013). Mandiri Belajar Analisis Data dengan SPSS. Yogyakarta: Mediakom

Rachmawati, Ike Kusdyah. (2008). Manajemen Sumber Daya Manusia. Yogyakarta: CV Andi Offset.

Robbins, Stephen P. and Judge, Timothy A. (2013). Organizational Behavior. New Jersey: Pearson Education.

Sedarmayanti. (2014). Manajemen Sumber Daya Manusia: Reformasi Birokrasi dan Manajemen Pegawai Negeri Sipil. Bandung: Refika Aditama.

Sekaran, Uma. (2015). Metodologi Penelitian untuk Bisnis. Jakarta: Salemba Empat.

Siagian, Sondang P.( 2015). Manajemen Sumber Daya Manusia. Jakarta: Bumi Aksara.

Sokro, Evans. (2012). Analysis of the Relationship That Exists Between Organizational Culture Motivation and Performance. Problems Of Management In The 21st Century. Vol 3.

Sudarman, Dadang; Harsani, Prihastuti dan Qur'ania, Arie. (2014). Aplikasi Sistem Penilaian Kinerja Pegawai Negeri Sipil Berbasis Web (Studi Kasus : Balai Penelitian Ternak). SkripsiProgram Studi IImu Komputer. Fakultas Matematika dan IImu Pengetahuan Alam. Bogor: Universitas Pakuan

Sugiyono. (2012). Metode Penelitian Kuantitatif, Kualitatif dan R\&D. Bandung: Penerbit Alfabeta

Tampi, Bryan Johanes. (2014). Pengaruh Gaya kepemimpinan dan motivasi terhadap kinerja karyawan pada PT Bank Negara Indonesia tbk (Regional sales Manado). Journal "Acta Diurna" Volume III. No.4. Tahun 2014

Torang, Syamsir.(2013). Organisasi dan Manajemen (Perilaku, Struktur, Budaya \& Perubahan Organisasi. Alfabeta. Bandung.

Vita, Bernadine. (2015). Pengaruh Gaya Kepemimpinan, Budaya Organisasi dan Lingkungan kerja terhadap Kinerja Guru dan karyawan pada yayasan Tri Asih Jakarta. Jurnal. Program Studi Manajemen. Fakultas Ekonomi Yogyakarta: Universitas Atma Jaya. 
Waliningsuci, Trias; Musadieq, M. Al dan Hamid, Djamhur. (2011). Pengaruh Budaya Organisasi dan gaya Kepemimpinan terhadap Kepuasan Kerja dan Kinerja (Studi Pada Karyawan PT Entrepreneus Independent Bank (EIB) Indonesia Surabaya). Jurnal. Fakultas IImu Administrasi. Malang: Universitas Brawijaya.

Wambugu, Lydiah Wairimu. (2014). Effect of Organizational Culture on Employee Performance (case Study of Wartsila-Kipevu Li Power Plant). European Journal of Business and Management Vol.6, No.32, 2014.

Zikmund, William G. et.al. (2010). Busness Research Methods. South Western USA: Cengage Learning. 